\title{
The over-the-scope clip system - a novel technique for gastrocutaneous fistula closure: The first North American experience
}

\author{
Truptesh H Kothari MD MS, Gregory Haber MD FRCP, Niket Sonpal MD, Nithin Karanth MD
}

TH Kothari, G Haber, N Sonpal, N Karanth. The over-thescope clip system - a novel technique for gastrocutaneous fistula closure. The first North American experience. Can J Gastroenterol 2012;26(4):193-195.

BACKGROUND: The mainstay of therapy for gastrocutaneous (GC) fistulas has been surgical intervention. However, endoclips are currently used for management of perforations and fistulas but are limited by their ability to entrap and hold the tissue.

OBJECTIVE: To report the first North American experience with a commercially available over-the-scope clip (OTSC) device, a novel and new tool for the endoscopic entrapment of tissue for the closure of fistula and perforations.

METHODS: The present single-centre study was conducted at a tertiary referral academic gastroenterology unit and centre for advanced therapeutic endoscopy and involved patients referred for endoscopic treatment for the closure of a GC fistula. The OTSC device was mounted on the tip of the endoscope and passed into the stomach to the level of the fistula. The targeted site of the fistula was grasped with the tissue anchoring tripod and pulled into the cap with concomitant scope channel suction. Once the tissue was trapped in the cap, a 'bear claw' clip was deployed.

RESULTS: The patients recovered with fistula closure. No complication or recurrence was noted. Fistula sizes $>1 \mathrm{~cm}$, however, were difficult to close with the OTSC system. The length of stay of the bear claw clip at the fistula site is unpredictable, which may lead to incomplete closure of the fistula.

CONCLUSION: Closure of a GC fistula using a novel 'bear claw' clip system is feasible and safe.

Key Words: Clip; Closure; Fistula; Gastrocutaneous; Leak; Perforation

\section{Le système d'agrafe sur endoscope - une nouvelle technique de fermeture des fistules gastrocutanées : La première expérience nord-américaine}

HISTORIQUE : L'intervention chirurgicale constitue le pilier du traitement des fistules gastrocutanées (GC). Cependant, les endoagrafes sont désormais utilisées pour prendre en charge les perforations et les fistules, mais sont limitées par leur capacité de piéger et de tenir les tissus.

OBJECTIF : Rendre compte de la première expérience nord-américaine d'une agrafe sur endoscope sur le marché, un outil nouveau et novateur pour piéger les tissus par voie endoscopique afin de fermer des fistules et des perforations.

MÉTHODOLOGIE : Les chercheurs ont mené la présente étude monocentrique dans une unité de gastroentérologie universitaire de soins tertiaires et un centre d'endoscopie thérapeutique avancée, auprès de patients aiguillés afin de subir un traitement endoscopique pour fermer une fistule GC. L'agrafe sur endoscope était fixée à l'extrémité de l'endoscope et insérée dans l'estomac jusqu'à la fistule. Le foyer ciblé de la fistule était saisi au moyen du trépied d'ancrage de tissu et tiré dans le capuchon par aspiration concomitante par voie endoscopique. Une fois les tissus piégés dans le capuchon, une agrafe « en patte d'ours " était déployée.

RÉSULTATS : Les patients se sont rétablis de la fermeture de la fistule, sans complication ni récurrence. Les fistules de plus de $1 \mathrm{~cm}$ étaient toutefois difficiles à fermer au moyen de l'agrafe sur endoscope. La durée du maintien de l'agrafe en patte d'ours au foyer de la fistule est imprévisible, ce qui peut susciter une fermeture incomplète de la fistule.

CONCLUSION : Il est faisable et sécuritaire de fermer une fistule GC au moyen d'un nouveau système d'agrafe « en patte d'ours ».

\footnotetext{
The mainstay of therapy for gastrocutaneous (GC) fistulas has been surgical intervention (1). However, a conservative endoscopic approach has recently been preferred, with the advantages of negligible morbidity and mortality, a short hospital stay and the possibility of prompt resumption of an oral diet (2). Routine endoscopic methods to close gastrointestinal (GI) fistulas include stents, injectables, stitch devices and endoclips (Table 1); however, endoclips are currently used for management of perforations and fistulas but are limited by their ability to entrap and hold the tissue. The Over the Scope Clip (OTSC, Ovesco AG, Germany) system is a new tool for the endoscopic entrapment of tissue. Indications for its use are hemostasis, compression of large vessels, and closure of leaks or fistulas of the GI tract. Preclinical work has shown the device to be feasible and safe for the closure of gastric, duodenal and colonic perforations up to $20 \mathrm{~mm}$ in diameter $(1,2)$. In the past three years (Table 2), several reports from Europe have attested to the efficacy of this device, but to date, there is no published North American experience. We present a case of an iatrogenic fistula successfully treated with the OTSC system.
}

\section{METHODS}

\section{Patient}

The procedure was performed at Lenox Hill Hospital, New York (USA). Informed written consent was obtained from the patient. An 80-year-old woman with a medical history including hypertension, aortic valve regurgitation and replacement, anemia and bacteremia presented with a longstanding GC fistula. The patient had originally undergone a transesophageal echocardiogram, which resulted in an esophageal perforation. Postsurgical repair included the placement of a feeding jejunostomy tube and venting gastrostomy tube. Subsequently, the patient was able to tolerate oral feeding. After removal of both the jejunostomy and gastrostomy tubes, the GC fistula persistently drained for nine months despite maximal acid suppression. Her course was complicated by persistent iron deficiency anemia, which required transfusions of intravenous dextran and packed red blood cells. The patient presented to the clinic as an outpatient for evaluation of endoscopic closure of the fistula. It was then decided the patient would be an excellent candidate for the OTSC system. A computed tomography

Lenox Hill Hospital, New York, New York, USA

Correspondence: Dr Truptesh Kothari, Department of Gastroenterology, Lenox Hill Hospital, 100, East 77th Street, New York, New York 10075, USA.

Telephone 952-412-3685, e-mail itskots@gmail.com

Received for publication October 31, 2011. Accepted November 17, 2011 
TABLE 1

\section{Endoscopic management of gastrocutaneous fistulas}

\begin{tabular}{|c|c|}
\hline Device & Trade name \\
\hline \multicolumn{2}{|c|}{ Mechanical closure devices } \\
\hline \multirow[t]{5}{*}{ Clips } & Bear Claw (OTSC System, Ovesco, Germany) \\
\hline & Endoclip or Quick Clip (Olympus Medical Systems, USA) \\
\hline & Triclip (Cook Medical, USA) \\
\hline & Resolution Clip (Boston Scientific, USA) \\
\hline & Multi Clip - Inscope (Ethicon, USA) \\
\hline Loops & Endoloop (Olympus Medical Systems, USA) \\
\hline \multirow[t]{3}{*}{ Sutures } & Suture EndoCinch (Bard Medical, USA) \\
\hline & g-Prox (USGI Medical, USA) \\
\hline & Eagle Claw (Apollo Group, USA) \\
\hline \multirow[t]{5}{*}{ Stents } & ALIMAXX-ES (Merit Endotek, USA) \\
\hline & WallFlex Partially and Fully covered (Boston Scientific, USA) \\
\hline & Polyflex Esophageal (Boston Scientific, USA) \\
\hline & Ultraflex ${ }^{\mathrm{TM}}$ Esophageal NG Stent (Boston Scientific, USA) \\
\hline & Bonastent (Endochoice Inc, USA) \\
\hline Injectables & SIS Fistula Plug (Cook Biotech, USA) \\
\hline and & Cyanoacrylate injection - Histoacryl (B Braun), Glubran (GEM) \\
\hline $\begin{array}{l}\text { coagu- } \\
\text { lants }\end{array}$ & $\begin{array}{l}\text { Fibrin injectable glue - Tisseel (Baxter, USA), Hemaseel } \\
\text { (HemAcure, UK), Beriplast P (CSL Surgery, USA) }\end{array}$ \\
\hline
\end{tabular}

OTSC Over-the-scope clip; UK United Kingdom

TABLE 2

Summary of the over-the-scope clip literature

\begin{tabular}{lrlc}
\hline Author (reference), year & Patients, $\mathbf{n}$ & Type of lesion & Success rate, \% \\
\hline Kirschiniak et al (5), 2007 & 11 & Gl bleeds & 100 \\
Repici et al (6), 2009 & 9 & Gl bleeds & 100 \\
Parodi et al (4), 2010 & 10 & 2 gastric leaks & 80 \\
& & 2 duodenal leaks & \\
Manta et al (7), 2010 & 12 & F colonic leaks & \\
Pohl et al (11), 2010 & 2 & Leaks & 91.7 \\
von Renteln et al (8), 2010 & 4 & Fistula & 50 \\
Albert et al (12), 2011 & 19 & Leaks & 50 \\
\hline
\end{tabular}

Gl Gastrointestinal

scan with oral contrast revealed a moderate hiatal hernia, pleural thickening consistent with previous perforation, empyema as well as contrast extravasation through the GC fistula.

\section{Bear claw technique}

The OTSC system is composed of an application cap, which is mounted onto the distal tip of an endoscope and a connected releasing mechanism installed on the handle of the scope. Three different variants of the clip consisting of a shape-memory alloy (nitinol) are available: the 'traumatic'; the 'atraumatic'; and the gastric fistula closure (Figure 1). In contrast to common endoscopic clips, the OTSC is able to compress larger quantities of tissue. There are two proprietary devices to draw the tissue into the cap: a dual arm forceps and a tissue anchoring tripod. The clip is deployed by a string release fixed to a rotating wheel attached to the accessory channel.

The single-channel endoscope (Olympus Medical Systems, USA) was introduced through the mouth and advanced down to the level of a hiatal hernia sac where previously placed surgical sutures from the esophageal perforation were seen adjacent to the gastroesophageal junction. The lesser curvature revealed normal findings, whereas the greater curvature revealed a retracted mucosal surface at the proximal body in continuity with the gastrostomy site on the anterior abdominal wall. A Savary guide wire was advanced through the skin opening of the GC fistula through the abdominal wall and into the stomach (Figure 2). The OTSC system was mounted on the tip of the scope and passed down into the stomach to the level of the fistula. The targeted

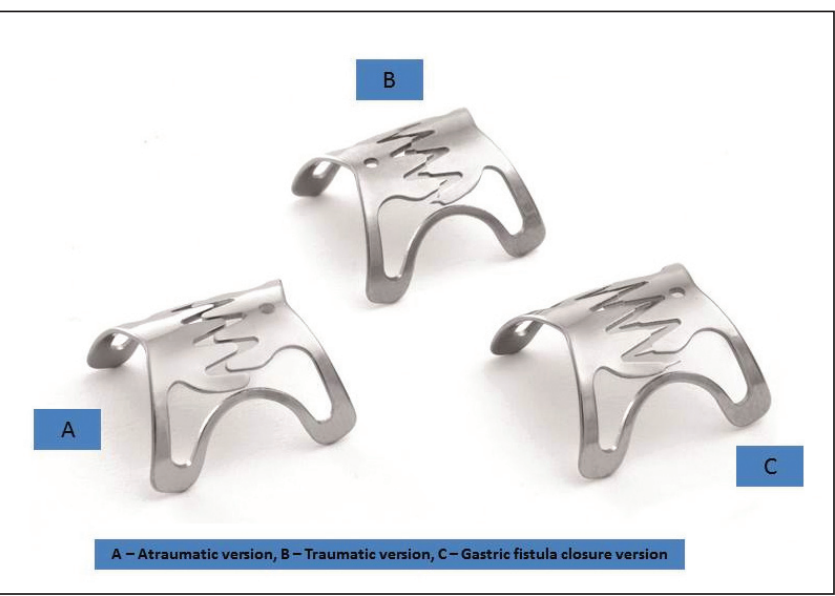

Figure 1) Different types of over-the-scope clips. A Atraumatic version used for gastrointestinal bleeds. B Traumatic version used for closure of leaks. C Gastric fistula closure version

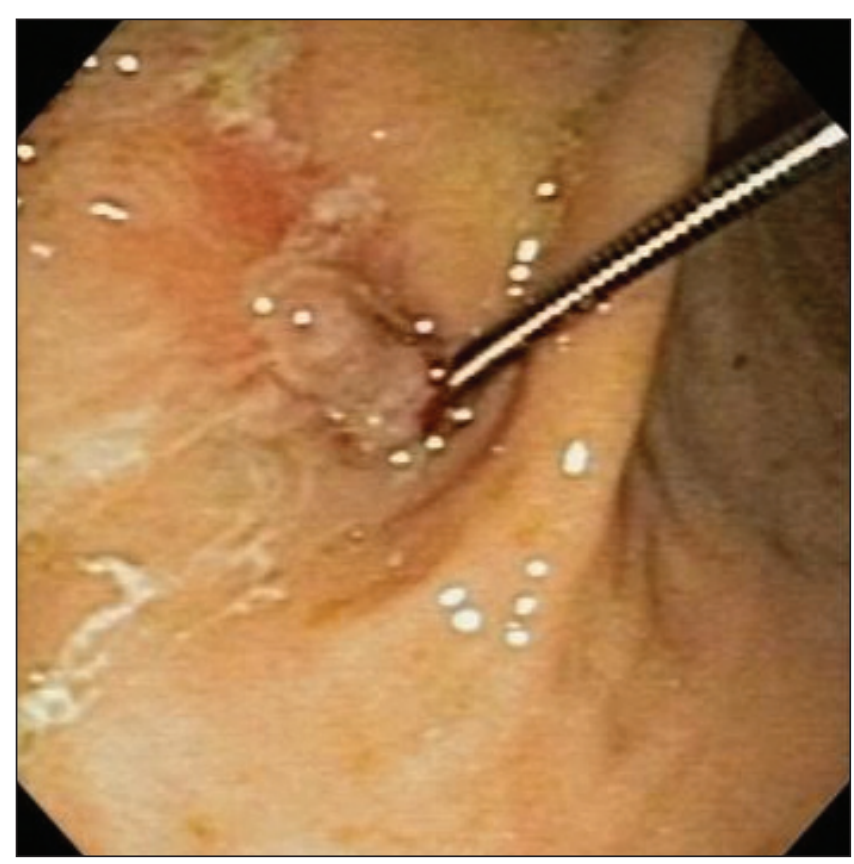

Figure 2) A Savary guide wire advanced through the skin opening of the gastrocutaneous fistula through the abdominal wall and into the stomach

site of the fistula was grasped with the tissue-anchoring tripod and pulled into the cap with concomitant scope channel suction. Once the tissue was trapped in the cap, the bear claw clip was deployed.

There was a small recessed area immediately adjacent to the released bear claw. Because it was uncertain as to whether this represented a corner of the fistulous opening and to ensure the closure of the first clip, a second bear claw clip was deployed in the left aspect of the previously placed bear claw (Figure 3 ). The Savary wire was then used to probe the fistulous tract from the skin into the stomach but could not be passed with the bear claw clips in position.

\section{RESULTS}

The patient was discharged home on ciprofloxacin and metronidazole for one week. At the three-month follow-up, the area of the previous GC fistula had healed entirely (Figure 4). A metallic object was seen in a pool of retained food debris in the stomach. A Roth net was used to grab the object, which appeared to be two retained bear claws. After the scope was withdrawn, it was apparent that the two original bear claw clips, which were deployed three months earlier, were stacked together. 


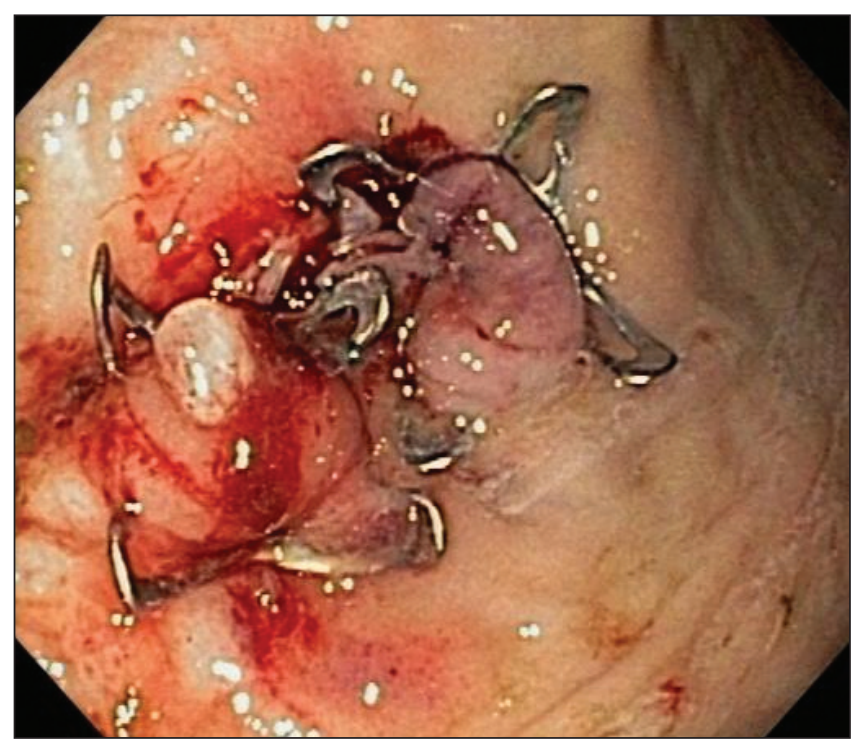

Figure 3) Bear claw clips deployed at the fistula site

\section{DISCUSSION}

In 1993, Binmoeller et al (3) reported on the first successful use of hemoclips to close a gastric perforation. Since then, multiple stitches, staple or clip devices have been used in attempting endoscopic closure of full-thickness defects. Parodi et al (4) reported on 10 patients with GI leaks from perforations, fistulas and anastomotic dehiscence. Two gastric, two duodenal and six colonic leaks were treated with the OTSC device. The diameter of leaks ranged between $7 \mathrm{~mm}$ and $20 \mathrm{~mm}$. In a study by Kirschniak et al (5), 11 patients with severe bleeding, deep wall lesions or perforations of the GI tract were successfully treated. In a third series by Repici et al (6), nine patients with bleeding and/or perforations of the GI tract were treated with the OTSC system. In 12 consecutive patients, Manta et al (7) found that placement of $9.5 \mathrm{~mm}$ or $10.5 \mathrm{~mm}$ OTSC led to fistula healing, and was confirmed by endoscopic and radiological methods. In this system, the bear claw clip failed only once and no complications of the OTSC were noted.

A study by von Renteln et al (8) demonstrated the limitations of the OTSC system with unsuccessful placement of two clips in two successive patients. The initial closure attempts in one esophagopulmonary fistula and one jejunocutaneous fistula using OTSCs were not successful because of chronic fibrotic changes and scarring at the fistula site. Severe fibrosis and scarring may limit the ability to draw tissue into the applicator cap, precluding successful OTSC deployment and feasibility.

In an attempt to treat failed gastrojejunal bypass in 2010, Heylen et al (9) also demonstrated that the OTSC system can be effective in

\section{REFERENCES}

1. Schurr MO, Arezzo A, Ho CN, et al. The OTEC clip for endoscopic organ closure in NOTES: device and technique. Minim Invasive Ther Allied Technol 2008;17:262-6.

2. Voermans RP, van Berge Henegouwen MI, Bemelman WA, et al. Novel over-the-scope-clip system for gastrotomy closure in natural orifice transluminal endoscopic surgery (NOTES): An ex vivo comparison study. Endoscopy 2009;41:1052-5

3. Binmoeller KF, Grimm H, Soehendra N. Endoscopic closure of a perforation using metallic clips after snare excision of a gastric leiomyoma. Gastrointest Endosc 1993;39:172-4.

4. Parodi A, Repici A, Pedroni A, Blanchi S, Conio M. Endoscopic management of GI perforations with a new over-the-scope clip device. Gastrointest Endosc 2010;72:881-6.

5. Kirschniak A, Kratt T, Stüker D, Braun A, Schurr MO, Königsrainer A. A new endoscopic over-the-scope clip system for treatment of lesions and bleeding in the GI tract: First clinical experiences. Gastrointest Endosc 2007;66:162-7.

6. Repici, A. Arezzo, G. De Caro, et al. Clinical experience with a new endoscopic over-the-scope clip system for use in the GI tract. Dig Liver Dis 2009;41:406-10.

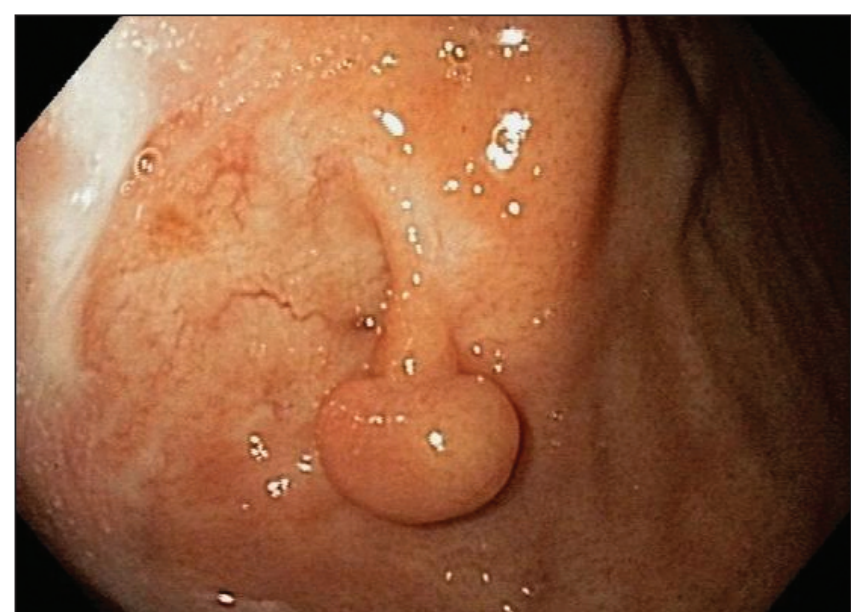

Figure 4) Healed gastrocutaneous fistula

maintaining the Fobi pouch (combination of stomach reduction and gastric bypass), aiding in additional weight loss. An OTSC was applied to narrow the pouch outlet in 94 patients following gastric bypass after unintended weight gain due to dilation of the gastrojejunostomy anastomosis. At the time of OTSC application, the mean $( \pm \mathrm{SD})$ body mass index was $29.7 \pm 1.8 \mathrm{~kg} / \mathrm{m}^{2}$ compared with $27.4 \pm 3.8 \mathrm{~kg} / \mathrm{m}^{2}$ at a mean follow-up of $352 \pm 66$ days. Additionally, Iacopini et al (10) demonstrated that the OTSC system could be applied to close fistulas subsequent to gastric band erosion and penetration. After placement, the external fistula closed and both OTSCs were lost spontaneously after four weeks (11).

\section{CONCLUSION}

The results from several studies $(1-3,12)$ and our case demonstrate the efficacy of the OTSC system in the closure of the GC fistula.

\section{SUMMARY}

Current methods for closure of GC fistula include stents, injectables, stitch devices and endoclips. Limitations are the ability to entrap and hold the tissue.

The significance of the OTSC system is its nonsurgical approach. The most important concept is the resultant outcome without complications. This device can be used for closure of GC fistula, GI leaks, enterocutaneous fistula, rectovaginal fistula, etc.

DISCLOSURES: Gregory Haber is a consultant for Ovesco Endoscopy AG, Germany. Truptesh Kothari, Niket Sonpal and Nithin Karanth have no financial disclosures or conflicts of interest to declare.

7. Manta R, Manno M, Bertani H, et al. Endoscopic treatment of gastrointestinal fistulas using an over-the-scope clip (OTSC) device: Case series from a tertiary referral center. Endoscopy 2011:43:545-8.

8. von Renteln D, Denzer UW, Schachschal G, Anders M, Groth S, Rösch T. Endoscopic closure of GI fistulae by using an over-thescope clip (with videos). Gastrointest Endosc 2010;72:1289-96.

9. Heylen AM, Jacobs A, Lybeer M, Prosst RL. The OTSC ${ }^{\circledR}$-Clip in revisional endoscopy against weight gain after bariatric gastric bypass surgery. Obes Surg 2011;21:1629-33.

10. Iacopini F, Di Lorenzo N, Altorio F, Schurr MO, Scozzarro A. Over-the-scope clip closure of two chronic fistulas after gastric band penetration. World J Gastroenterol 2010;16:1665-9

11. Pohl J, Borgulya M, Lorenz D, Ell C. Endoscopic closure of postoperative esophageal leaks with a novel over-the-scope clip system. Endoscopy 2010;42:757-9.

12. Albert JG, Friedrich-Rust M, Woeste G, et al. Benefit of a clipping device in use in intestinal bleeding and intestinal leakage. Gastrointest Endosc 2011;74:389-96. 


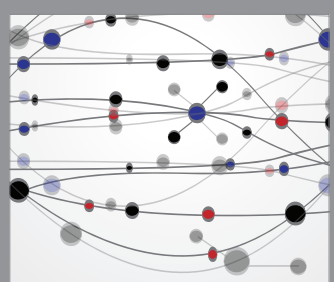

The Scientific World Journal
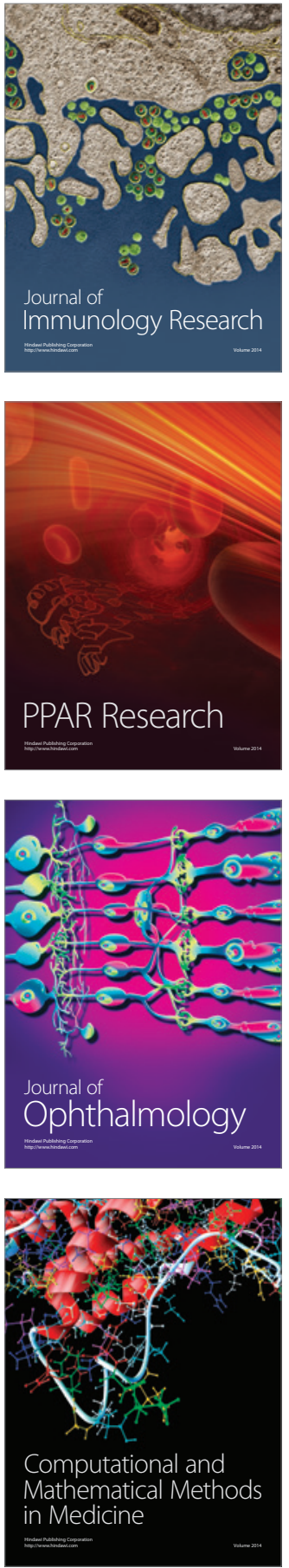

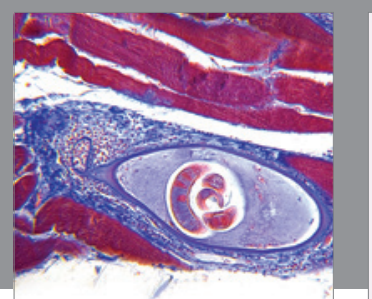

Gastroenterology Research and Practice

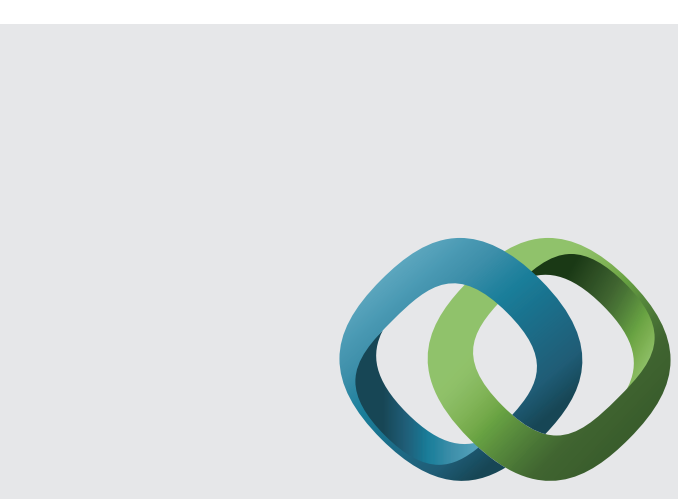

\section{Hindawi}

Submit your manuscripts at

http://www.hindawi.com
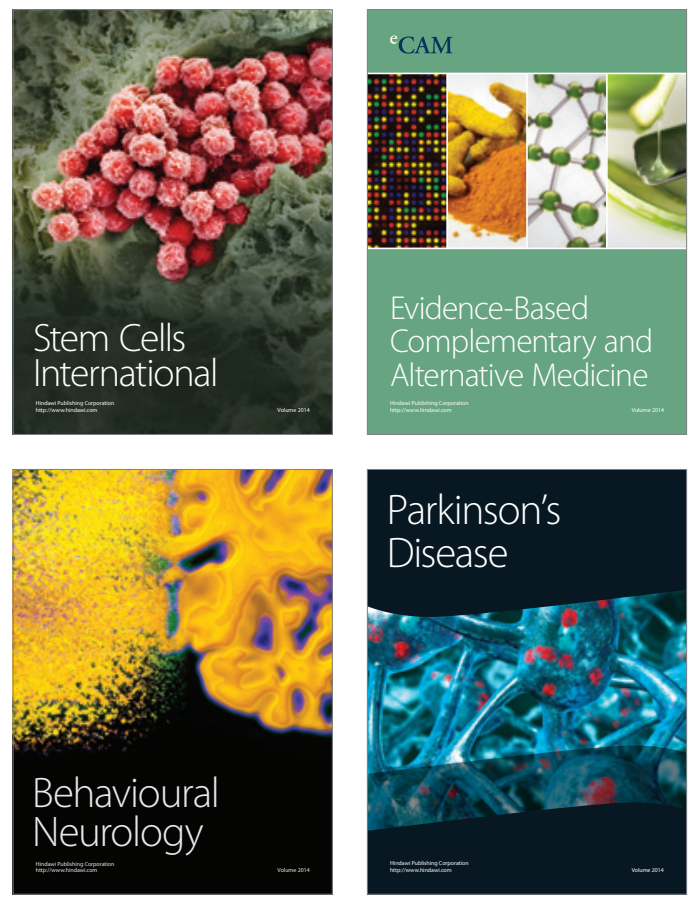
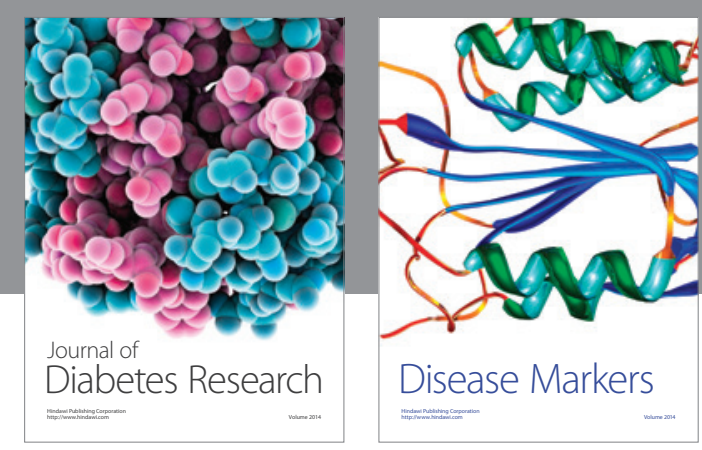

Disease Markers
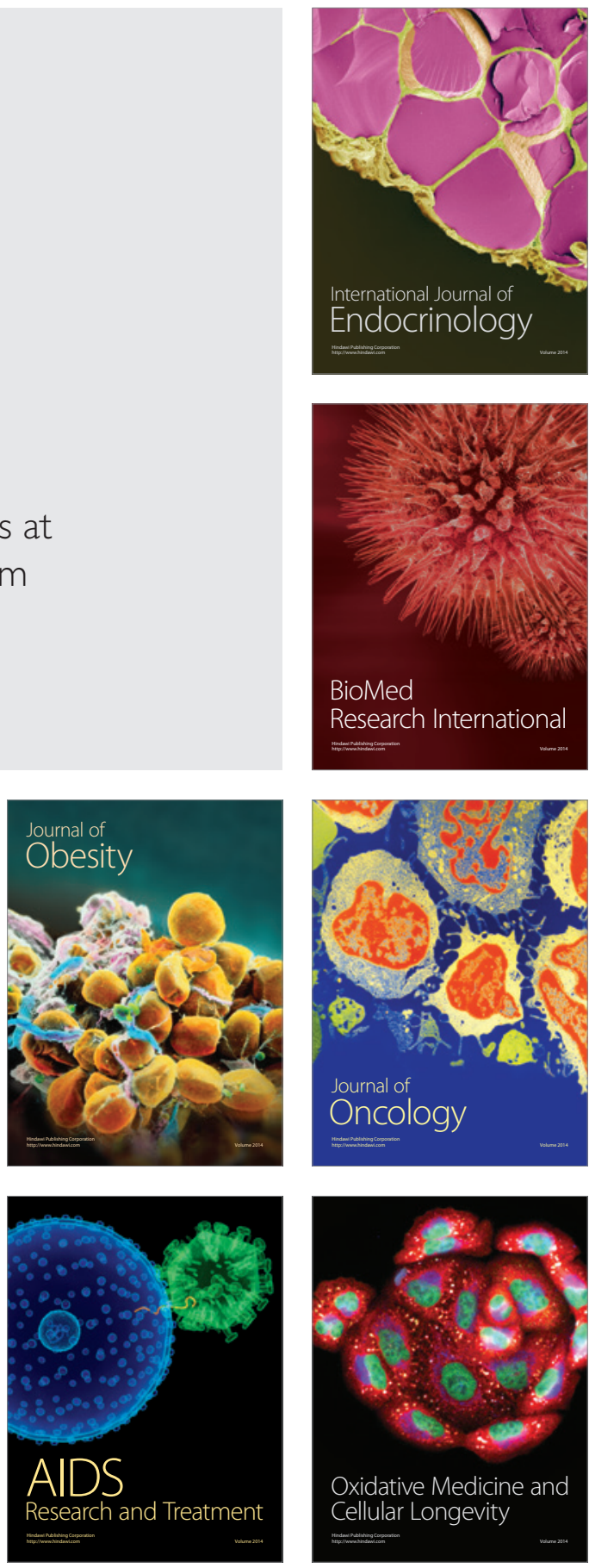